Informatika i sistemy upravleniya. - 2017. - No. 3(53). - P. 125-132.

Kerimkulova G.K. (gulsaat@mail.ru), Askalieva G.O.

Institute of automatic equipment and information technologies

\title{
ABOUT LIMITS OF APPLICABILITY OF THE INDICATIVE PROFILE OF THE WATER TUR- BIDITY BY E.V. KLEVTSOV
}

There has been implemented an $\mathrm{O}^{\text {пाм }}$ model restriction of applicability of the indicative profile of water turbidity by E.V. Klevtsov to conditions of the average and small rivers of the mountain zone of Kyrgyzstan. Specified restriction represents sets of boundary values of bias and relative roughness of stream bottom, parameters of indicative velocity profiles and water turbidity, maximum speed of water and extreme coordinate of the minimum (nonzero) water turbidity at the fixed density composition (or fineness) of the suspended sediment load.

Keywords: water speed profile; distribution of stream turbidity; parameters $\mathrm{m}$ and $\beta^{*}$ of the specified distributions; limit of applicability.

DOI: 10.22250/isu.2017.53.125-132

For citation:

Kerimkulova G.K., Askalieva G.O. ABOUT LIMITS OF APPLICABILITY OF THE INDICATIVE PROFILE OF THE WATER TURBIDITY BY E.V. KLEVTSOV // Informatika i sistemy upravleniya. - 2017. - No. 3(53). - P. 25-132. 